Cornell University Law School Scholarship@Cornell Law: A Digital Repository

Cornell Law Faculty Publications

Faculty Scholarship

Winter 2018

\title{
Evaluating Employment Arbitration: A Call for Better Empirical Research
}

Samuel Estreicher

New York University Law School

Michael Heise

Cornell Law School, michael.heise@cornell.edu

David Sherwyn

Cornell University School of Hotel Administration

Follow this and additional works at: https://scholarship.law.cornell.edu/facpub

Part of the Dispute Resolution and Arbitration Commons, and the Labor and Employment Law Commons

\section{Recommended Citation}

Estreicher, Samuel and Heise, Michael and Sherwyn, David, "Evaluating Employment Arbitration: A Call for Better Empirical Research," 70 Rutgers University Law Review 375 (2018)

This Article is brought to you for free and open access by the Faculty Scholarship at Scholarship@Cornell Law: A Digital Repository. It has been accepted for inclusion in Cornell Law Faculty Publications by an authorized administrator of Scholarship@Cornell Law: A Digital Repository. For more information, please contact jmp8@cornell.edu. 


\title{
Evaluating Employment Arbitration: A CAll For BETTER EMPIRICAL RESEARCH
}

\author{
Samuel Estreicher ${ }^{\star}$, Michael Heise $e^{\dagger} \&$ David S. Sherwyn ${ }^{\ddagger}$
}

I. INTRODUCTION

II. OVERVIEW OF U.S. ARBITRATION LAW .............................................376

III. EMPIRICAL WORK ON EMPLOYMENT ARBITRATION.............................382

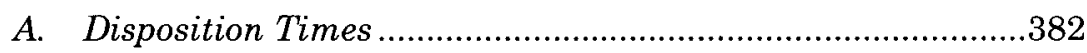

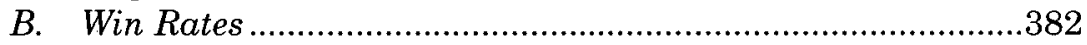

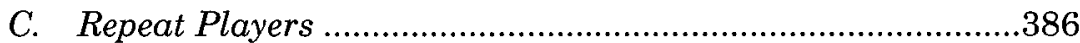

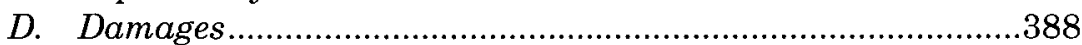

IV. EVALUATION OF EXISTING EMPIRICAL WORK.........................................389

A. Using EEOC Filings and Dispositions as a Proxy for the

Universe of Employment Law Claims ...............................389

B. Cases Resolved at Trial Are Not Representative of the

Universe of Employment Law Claims ................................394

V. Possible RESEARCH DESIGNS GoING ForWARD .................................397

\section{INTRODUCTION}

Since at least 1991, issues surrounding mandatory arbitration of employment and other disputes ${ }^{1}$ have intrigued, perplexed, angered, gratified, and confounded academics, politicians, lawyers, and others.

* Samuel Estreicher, Dwight D. Opperman Professor of Labor Law and Director, Center for Labor and Employment Law, N.Y.U. School of Law.

$\dagger$ Michael Heise, Professor of Law, Cornell Law School.

$\ddagger$ David S. Sherwyn, John and Melissa Ceriale Professor of Hospitality Human Resources and Director of the Cornell Institute for Hospitality Labor and Employment Relations, Cornell School of Hotel Administration.

1. This paper deals only with mandatory arbitration of employment disputes. The issues concerning mandatory arbitration of consumer disputes are more difficult because some consumer disputes are not amenable to individualized claims, whether in arbitration or litigation. See generally Christopher R. Drahozal, AAA Consumer Arbitration, in BEYOND ELITE LAW: ACCESS TO CIVIL JUSTICE IN AMERICA 478, 478-92 (Samuel Estreicher \& Joy Radice eds., 2016); Christopher R. Drahozal \& Samantha Zyontz, An Empirical Study of AAA Consumer Arbitrations, 25 OHIO ST. J. ON DISP. RESOL. 843, 843-930 (2010); Peter B. Rutledge, Saturns for Rickshaws: Lessons for Consumer Arbitration and Access to Justice, in BEYOND ELITE LAW: ACCESS TO CIVIL JUSTICE IN AMERICA, supra, at 493, 493-505. 
Similar to many legal issues, the first wave of scholarly work centered on the law. As the law has pretty much settled, academics have turned to empirical work, focusing on how employment arbitration works, and how it compares to employment litigation. In part due to pressure from California legislation, ${ }^{2}$ the American Arbitration Association ("AAA"), the nation's leading provider of arbitration services, opened access to its data base. Owing to inevitable data limitations, most analyses have focused on outcomes-comparisons between litigation verdicts/judgments and arbitration awards.

We wholeheartedly endorse good empirical work as an important means of understanding and addressing controversial policy issues, especially in the arbitration arena, and tried our hand at such work a decade ago. ${ }^{3}$ We have written this paper to encourage research that goes beyond evaluating awards within the AAA data set and to engage in a longitudinal study of the history of claims-from when they are initially filed with administrative agencies or arbitration organizations to when they are settled or adjudicated.

After an overview of U.S. arbitration law with respect to employment claims, we examine current empirical work in this area, highlight its relevance, identify its limitations, and outline the broad contours of the type of work we believe is needed to advance the policy debate.

\section{OVERVIEW OF U.S. ARBITRATION LAW}

The initial U.S. common law position on arbitration was one of hostility. Courts viewed arbitration as a mechanism designed by private parties to oust courts from their customary position as the principal societal agent for dispute resolution. ${ }^{4}$ This hostility expressed itself in the doctrine that specific performance was not available to enforce arbitration promises until they resulted in an award and, even then, the award would face difficulty obtaining enforcement in the courts. ${ }^{5}$ Since this judicial position stymied commercial actors seeking to find a way of resolving disputes without undergoing the expense, delay, and publicity of lawsuits, a number of states passed arbitration acts to make

2. See CAL. CTV. Proc. CoDE $\S 1281.96$ (West 2015).

3. See generally David Sherwyn, Samuel Estreicher \& Michael Heise, Assessing the Case for Employment Arbitration: A New Path for Empirical Research, 57 STAN. L. REV. 1557 (2005).

4. See Red Cross Line v. Atl. Fruit Co., 264 U.S. 109, 120-21 (1924) (discussing the common law rule). See also Sherwyn, Estreicher \& Heise, supra note 3, at 1574 n.88.

5. See Red Cross Line, 264 U.S. at 120-21. 
executory arbitration promises enforceable. ${ }^{6}$ This process culminated in the enactment of the United States Arbitration Act in 1925, now referred to as the Federal Arbitration Act ("FAA"). ${ }^{7}$ The FAA declares that all arbitration agreements "evidencing a transaction involving commerce to settle" a dispute arising out of such transaction, whether it be a future dispute or a dispute over an existing controversy "shall be valid, irrevocable, and enforceable, save upon such grounds as exist at law or in equity for the revocation of any contract." 8

Over the last ninety years, the Supreme Court has steadily resolved issues over the scope of the FAA in favor of arbitration. ${ }^{9}$ In Prima Paint Corp. v. Flood \& Conklin Manufacturing Co., the Court held that the statute applied in state (as well as federal) courts and adopted the socalled "separability" doctrine providing that claims of fraud, and presumably other grounds of invalidity, could not nullify an arbitration agreement unless the complained-of fraud occurred in securing the arbitration promise itself. ${ }^{10}$ Any doubts concerning whether the "evidencing a transaction involving commerce" language confined the FAA to 1925 notions of the federal power to regulate interstate commerce were laid to rest in 1995,11 and a vigorous doctrine of FAA preemption developed to render null state law attempts to disfavor arbitration or regulate arbitration agreements differently than other contracts. ${ }^{12}$

Perhaps the biggest boost to arbitration came in the mid-1980s with the Supreme Court's willingness to narrow, and in some cases overrule, earlier decisions questioning whether the FAA required enforcement of promises to arbitrate disputes governed by statutory law. ${ }^{13}$ These

6. See Sidney P. Simpson, Specific Enforcement of Arbitration Contracts, 83 U. PA. L. REV. 160, 167-70 (1934) (listing several states that enacted their own arbitration legislation and noting a push for a federal arbitration act).

7. Federal Arbitration Act, Pub. L. No. 68-401, 43 Stat. 883 (1925) (codified as amended at 9 U.S.C. $\S \S 1-14(2012))$.

8. Federal Arbitration Act, 9 U.S.C. $\$ 2$ (2012).

9. See, e.g., Prima Paint Corp. v. Flood \& Conklin Mfg. Co., 388 U.S. 395, 403-04 (1967).

10. Id. at 421 .

11. See Allied-Bruce Terminix Cos. v. Dobson, 513 U.S. 265, 275 (1995).

12. See, e.g., Perry v. Thomas, 482 U.S. 483, 490-91 (1987) (holding preempted state wage payment claims despite state's declared policy that such claims "may be pursued without regard to private arbitration agreements"); Southland Corp. v. Keating, 465 U.S. 1,15 (1984) (holding preempted state high court interpretation barring arbitration of claims under California franchise investment law). See generally Christopher $\mathbf{R}$. Drahozal, Federal Arbitration Act Preemption, 79 IND. L.J. 393 (2004).

13. See, e.g., Wilko v. Swan, 346 U.S. 427 (1953), overruled by Rodriguez de Quijas v. Shearson/Am. Express, Inc., 490 U.S. 477, 485 (1989). See also infra notes 21-26 and accompanying text. 
decisions are particularly relevant to U.S. employment law, where most employment relationships are terminable at-will and any claims maintainable by employees (when not represented by labor unions) are as a general matter based on federal statutes rather than contract. ${ }^{14}$

A good illustration of this sea-change in FAA jurisprudence begins with Alexander v. Gardner-Denver Co., a 1974 decision. ${ }^{15}$ In that case, Alexander, a union member-employee, was fired and arbitrated his grievance under the employer's collective bargaining agreement with the union representing him. ${ }^{16}$ At the arbitration, Alexander alleged his employer discharged him because of his race. ${ }^{17}$ The arbitrator denied the grievance and held there was "just cause" for termination under the labor agreement. ${ }^{18}$ Subsequently, Alexander filed a race discrimination case under Title VII of the Civil Rights Act of 1964 ("Title VII") 19 in federal court, where the employer argued that arbitration was the exclusive forum for the dispute, and that, in any event, the employee had chosen to go to arbitration and could not relitigate a determination made by the arbitrator that was necessary to the result reached in the award. ${ }^{20}$

On review, the Supreme Court rejected the employer's argument and found that the arbitration did not preclude Alexander's Title VII lawsuit. ${ }^{21}$ The Court reasoned that while arbitration was appropriate to resolve the employee's contract claim, it was inappropriate for the statutory claim because arbitrators generally lack authority and competence to resolve statutory issues and, in this case, the union representing the interests of the bargaining unit, not simply Alexander's, controlled which matters would go to arbitration and which arguments would be made to the arbitrator. ${ }^{22}$

In keeping with its decisions in the 1980s extending the FAA to disputes governed by federal statutes ranging from the antitrust laws, ${ }^{23}$ the Racketeer-Influenced and Corrupt Organizations Act ("RICO"), ${ }^{24}$

14. See generally RESTATEMENT OF THE LAW, EMPLOYMENT LAW ch. 1 (AM. LAW INST. 2015).

15. 415 U.S. 36 (1974).

16. Id. at $38-40$.

17. Id. at 42 .

18. Id.

19. 42 U.S.C. $\S 2000 \mathrm{e}(2012)$.

20. See Gardner-Denver, 415 U.S. at $43,55-56$.

21. See id. at 59-60.

22. See id. at $53,56-58,58$ n. 19 .

23. See Mitsubishi Motors Corp. v. Soler Chrysler-Plymouth, Inc., 473 U.S. 614, 629 (1985) (holding antitrust disputes are subject to the FAA).

24. See Shearson/Am. Express, Inc. v. McMahon, 482 U.S. 220, 241-42 (1987) (holding RICO claims are subject to the FAA). 
and the federal securities laws, ${ }^{25}$ the Court signaled a departure from its view in Gardner-Denver regarding the authority and competence of arbitrators to deal with statutory employment claims in Gilmer $v$. Interstate/Johnson Lane Corp. in 1991. ${ }^{26}$

In Gilmer, the employee-petitioner was required to sign an arbitration agreement as a condition to accepting a position with Interstate/Johnson that involved working as a registered representative with the New York Stock Exchange ("NYSE"). ${ }^{27}$ The NYSE's rules required brokers and other registered agents to resolve all employment disputes in arbitration, organized under its auspices, and thus purported to preclude registered representatives from filing cases in court. ${ }^{28}$ After six years of employment, the company fired Gilmer, who then filed an action under the Age Discrimination in Employment Act of 1967 ("ADEA") 29 in federal court. ${ }^{30}$ The employer countered with a motion to compel arbitration under the FAA. ${ }^{31}$

The Gilmer Court held that arbitration should be compelled, and distinguished Gilmer's case from Alexander's in Gardner-Denver because Gilmer's promise to arbitrate stemmed from an individual contract between Gilmer and his employer ${ }^{32}$ and not a collective bargaining agreement between an employer and a labor union representing its employees. ${ }^{33}$ Moreover, the Gilmer Court rejected the

25. Rodriguez de Quijas v. Shearson/Am. Express, Inc., 490 U.S. 477, 482 (1989) (holding securities disputes are subject to the FAA); McMahon, 482 U.S. at 238 (same).

26. See 500 U.S. 20 (1991).

27. Id. at 23 .

28. See id.

29. 29 U.S.C. $\$ 621(2012)$.

30. See Gilmer, 500 U.S. at 23-24.

31. Id. at 24 .

32. Id. at 33-34. The Court left open the effect of the FAA exclusion for "contracts of employment of seamen, railroad employees, or any other class of workers engaged in foreign or interstate commerce." 9 U.S.C. $\$ 1$ (2012). Justice White's majority opinion explained that Gilmer had not raised the $\S 1$ exclusion point and, in any event, his arbitration promise was a condition of registration with the NYSE and not a condition of employment with his employer. Gilmer, 500 U.S. at 25 n.2. In Circuit City Stores, Inc. $v$. Adams, 532 U.S. 105 (2001), the Court read this exclusion narrowly to reach only contracts involving employees directly engaged in the transportation industry. Id. at 109. For pre-Circuit City commentary, see Samuel Estreicher, Predispute Agreements to Arbitrate Statutory Employment Claims, 72 N.Y.U. L. REV. 1344, 1369-71 (1997). See generally Samuel Estreicher, The Story of Gilmer v. Interstate Johnson/Lane Corp., in EMPLOYMENT LAW STORIES (Samuel Estreicher \& Gillian Lester eds., Foundation Press 2006).

33. See Gilmer, 500 U.S. at 33-34. In 14 Penn Plaza LLC v. Pyett, 556 U.S. 247 (2009), the Court rejected the argument that under Gardner-Denver labor arbitration pursuant to a collective bargaining agreement could not prevent litigation. See generally id. See also Samuel Estreicher, Living with Gardner-Denver, PERSPECTIVES ON WORK, Winter 2004, 
essential premise of Gardner-Denver that arbitrators were not competent to hear statutory claims such as Gilmer's ADEA claims. ${ }^{34}$

Gilmer also advanced several fairness issues - that the arbitration promise was not voluntarily made but was wrested as a condition of obtaining or maintaining employment, that the roster of arbitrators from which he would have to pick an arbiter was assembled by the NYSE, that there would be no written opinions, that discovery would be limited, and that damages were likely to be lower than in litigation. ${ }^{35}$ The Gilmer Court rejected these "generalized attacks on arbitration [as] 'rest[ing] on suspicion of arbitration as a method of weakening the protections afforded in the substantive law to would-be complainants,' and, as such, they are 'far out of step with our current strong endorsement of the federal statutes favoring this method of resolving disputes." 36 On Gilmer's "knowing and voluntary" waiver contention, the Court reiterated that unless the general law of contracts invalidated the agreement, the fact that the arbitration promise was contained in an adhesion contract did not preclude enforcement. ${ }^{37}$ Moreover, the NYSE rules provided for written awards, choice of arbitrator within the NYSE rosters (by permitting unlimited challenges for cause and one peremptory challenge), and did not preclude arbitrators from providing the full range of relief available in court. ${ }^{38}$ As for discovery, the Court noted, the point of arbitration is to obtain a more expeditious resolution than in court and no showing had been made that the NYSE rules afforded inadequate discovery to address claims. ${ }^{39}$

The Supreme Court has repeatedly emphasized that when a party agrees to arbitrate its claims, it agrees to a change in forum but "does not forgo the substantive rights afforded by the statute" the party is invoking. ${ }^{40}$ Accordingly, employment arbitrators must be given the authority to adjudicate statutory claims in accordance with substantive statutory requirements and award statutory remedies if violations are found.

at 23-26 (published originally by the Industrial Relations Research Association, which is now the Labor and Employment Relations Association (LERA)).

34. See Gilmer, 500 U.S. at 30-32.

35. See id.

36. Id. at 30 (quoting Rodriguez de Quijas v. Shearson/Am. Express, Inc., 490 U.S. $477,481(1989))$.

37. Id. at 33 ("Of course, courts should remain attuned to well-supported claims that the agreement to arbitrate resulted from the sort of fraud or overwhelming economic power that would provide grounds "for the revocation of any contract"' (quoting Mitsubishi Motors Corp. v. Soler Chrysler-Plymouth, Inc., 473 U.S. 614, 627 (1985)).

38. Id. at $30-32$.

39. See id. at 31 .

40. Id. at 26 (quoting Mitsubishi, 473 U.S. at 628). 
Gilmer's effect on FAA jurisprudence has been to preclude broadscale challenges to employment arbitration. The FAA erects a strong presumption of arbitrability requiring particularized challenges that, for example, employees were not given sufficient notice that in agreeing to arbitration they were giving up the right to a judicial forum, that the fees for invoking arbitration effectively barred access to the arbitral forum, or that the arbitration promise itself was unenforceable under generally applicable state law of unconscionability. ${ }^{41}$ Also, in 1995, leading arbitration organizations joined with the American Bar Association and plaintiff and defense groups to promulgate a "Due Process Protocol" which sets minimum standards for all employment arbitration agreements and programs. ${ }^{42}$ These include a right to representation (if you can afford it), an arbitrator who is well-versed in employment law, written opinions, and authorization to award the full range of statutory remedies available in court. ${ }^{43}$

Two open questions in this area include whether a provision in an arbitration agreement or program waiving the employee's right to bring a class or collective action is unenforceable because it violates a substantive right under the particular statute invoked by the plaintiff, and when the FAA must give way to a "contrary congressional command" 44 in another statute that a court action may proceed without regard to an arbitration promise or award. ${ }^{45}$

41. Richard A. Bales, The Employment Due Process Protocol at Ten: Twenty Unresolved Issues, and a Focus on Conflicts of Interest, 21 OHIO ST. J. ON DISP. RESOL. $165,185-95$ (2005).

42. Id. at $171-73$.

43. A Due Process Protocol for Mediation and Arbitration of Statutory Disputes Arising out of the Employment Relationship, AM. B. Ass'N (1997), https:// www.americanbar.org/newsletter/publications/gp_solo_magazine_home/gp_solo_magazine _index/lab_emp.html. See generally Bales, supra note 41, at 172-74; Samuel Estreicher \& Zev J. Eigen, The Forum for Adjudication of Employment Disputes, in RESEARCH HANDBOOK ON THE ECONOMICS OF LABOR AND EMPLOYMENT LAW 409 (Cynthia L. Estlund \& Michael L. Wachter eds., 2012). More recently, the National Academy of Arbitrators, a prestigious body of arbitrators, has promulgated guidelines to improve the process of arbitrator selection. See generally Theodore J. St. Antoine, Labor and Employment Arbitration Today: Mid-Life Crisis or New Golden Age?, 32 OHIo ST. J. ON DiSP. RESOL. 1, 17-19 (2017).

44. CompuCredit Corp. v. Greenwood, 565 U.S. 95, 103-04 (2012); Shearson/Am. Express, Inc. v. McMahon, 482 U.S 220, 226-27 (1987).

45. The extent to which administrative agency decisions or regulations can supply the requisite "contrary congressional command" to override the FAA is the subject of Epic Sys. Corp. v. Lewis, cert. granted, 137 S. Ct. 809 (2017) (Nos.16-285, et al.). See generally David L. Noll, Who Regulates Arbitration? 43-44 (Aug. 22, 2017) (unpublished manuscript) (on file with the Rutgers University Law Review). 


\section{EMPIRICAL WORK ON EMPLOYMENT ARBITRATION}

In our 2005 Stanford Law Review article, we examined previously published empirical work on employment arbitration. ${ }^{46}$ Specifically, these studies compared litigation to arbitration with respect to disposition time, win/loss records, the so-called "repeat player" effect, and damages. ${ }^{47}$ We focused on studies by Lewis Maltby, William M. Howard, Elizabeth Hill, Theodore Eisenberg, and Lisa B. Bingham. ${ }^{48}$ Since then, there have been substantial additions to the body of empirical work on employment arbitration.

\section{A. Disposition Times}

On the question of the average length of time between the filing of a claim and disposition, it is generally agreed that arbitration is faster than litigation. Maltby found that arbitration took less than half the time to resolve than litigation (679.5 days for litigation and 8.6 months in arbitration) ${ }^{49}$ In a 2011 paper, Colvin determined that litigation took 2.5 years from filing to trial while arbitration took just under one year (361.5 days), and suggested that employment arbitrations are taking longer than in the past. ${ }^{50}$ Even if the latter finding portends a trend, arbitration remains twice as fast as litigation, on average. ${ }^{51}$ One could argue, however, that the cases that go to arbitration are easier to resolve than the cases that end up in litigation and that may be a principal reason for the difference in disposition time. We are aware of no study that attempts to control for the complexity of the cases that go to litigation as opposed to arbitration.

\section{B. Win Rates}

The next question examined in these studies is whether claimant win rates are lower in arbitration than in litigation. Nielsen, Nelson, and Lancaster studied 1,672 cases filed in federal court between 1988 and $2003 .{ }^{52}$ Of the total number of cases filed, they found that $37 \%$ of

\footnotetext{
46. Sherwyn, Estreicher \& Heise, supra note 3, at 1557-91.

47. Id. at $1567-81$.

48. Id. at $1567 \mathrm{nn}, 33-38$.

49. Id. at 1572 .

50. Alexander J. S. Colvin, An Empirical Study of Employment Arbitration: Case Outcomes and Processes, 8 J. EMPIRICAL LEGAL STUD. 1, 8 (2011).

51. See id.

52. Laura Beth Nielsen et al., Individual Justice or Collective Legal Mobilization? Employment Discrimination Litigation in the Post Civil Rights United States, $7 \mathrm{~J}$. EMPIRICAL LEGAL STUD. 175, 176, 181 (2010).
} 
the cases were dismissed before trial (half on motions to dismiss and half on motions for summary judgment), $58 \%$ were settled before trial, and 100 cases $(6 \%)$ went to trial. ${ }^{53}$ Employees prevailed in 32 of the cases overall ( $2 \%$ of all the cases in their sample) and $32 \%$ of the cases that went to trial. 54

In our own review of 7316 AAA arbitration cases ${ }^{55}$ that closed during the 2012-2017 time period, $75.7 \%$ were settled and 847 cases $(11.6 \%)$ resulted in an arbitrator's award. ${ }^{56}$ The employee won $22.4 \%$ of the cases resulting in an award..$^{57}$

Colvin and Pike detected an increase in dismissal of arbitration cases before hearing, finding that summary judgment motions were filed in $28.9 \%$ of the cases (where they had access to the full file) and the arbitrators issued a full dismissal in $14.1 \%$ of the total number of cases and about $50 \%$ of the motions filed. ${ }^{58}$ They acknowledge that $14 \%$ is a distinct minority of cases, but note that "summary judgment has become a significant element in employment arbitration and that in a number of cases it results in the plaintiff not being able to obtain a hearing on the merits." 59

While Colvin and Pike are correct that summary judgment is becoming a somewhat more significant factor in arbitration, the incidence of summary judgments against claimants is a good deal lower than that found in litigation. Nielsen and co-authors found that in their 1998-2003 sample of 1672 litigated employment cases, $19 \%$ of the cases were dismissed, $50 \%$ of the cases were settled early, and plaintiffs lost on summary judgment in $18 \%$ of the cases. ${ }^{60}$ Maltby found that, in litigation, motions accounted for $60 \%$ of the judicial terminations and $98 \%$ of terminations went against the plaintiff. 61

53. See id. at 187.

54. See id. at 187.

55. The AAA dataset we used includes reported AAA arbitration results publicly available as of May 9, 2017.

56. The AAA dataset includes 1,595 filings involving Macy's that were originally coded as "dismissed." Further research, however, indicates that a substantial percentage (if not, in fact, all) of these Macy's filings originally coded as "dismissals" are, in fact, more accurately coded as "settled" disputes. If we exclude the originally coded Macy's-related "dismissals, "the resulting universe of A.AA arbitration results for the period in question drops from 7,316 to 5,721 filings, the settlement rate drops to $68.9 \%$ and the arbitral award percentage increases to $14.8 \%$.

57. AM. ARB. ASs'N, CONSUMER REP. Q3 2017 (on file with authors).

58. See Alexander J.S. Colvin \& Kelly Pike, Saturns and Rickshaws Revisited: What Kind of Employment Arbitration System Has Developed?, 29 OHIO ST. J. ON DISP. RESOL. 59,73 (2014).

59. Id.

60. Nielsen et al., supra note 52 , at 184,187 \& fig. 1 .

61. Sherwyn, Estreicher \& Heise, supra note 3, at 1569. 


\section{Comparison Studies on Arbitration and Litigation}

\begin{tabular}{|l|c|c|}
\hline \multicolumn{3}{|l|}{ Speed of Arbitration versus Speed of Litigation } \\
Study & Arbitration & Litigation \\
\hline Maltby & 201 days & 679 days \\
\hline Colvin & 361.5 days & 709 days \\
\hline
\end{tabular}

\begin{tabular}{|c|c|c|}
\hline \multicolumn{3}{|c|}{ Employee Win Rate in Arbitration versus Litigation } \\
\hline Study & Arbitration & Litigation \\
\hline Nielson, Nelson, and Lancaster & & $2 \%$ \\
\hline Howard & $68 \%$ & $28 \%$ \\
\hline Eisenberg and Hill & $26 \%$ & $36 \%$ \\
\hline Eisenberg & $\ldots$ & $\begin{array}{c}29.7 \% \\
\text { (of cases that } \\
\text { went to verdict) }\end{array}$ \\
\hline Colvin and Pike & $24.7 \%^{*}, 64.6 \% * *$ & $\ldots$ \\
\hline Hill & $34 \%$ & $\ldots$ \\
\hline Bingham & $27.6 \%$ & $\ldots$ \\
\hline Delikat and Kleiner & $46 \%$ & $33.6 \%$ \\
\hline
\end{tabular}

* Win rate where employer promulgated policies were the basis for arbitration

** Win rate for individually negotiated arbitration

In addition, Howard found that plaintiffs in court actions prevailed $28 \%$ of the time (38\% in front of juries and $19 \%$ in bench trials) as compared to AAA arbitrations where they prevailed $68 \%$ of the time. ${ }^{62}$ Eisenberg and Hill found an employee win rate in federal court civil rights cases of $36 \%$ and an arbitration win rate of $26 \%{ }^{63}$

In his final paper before his untimely death, our colleague Ted Eisenberg examined civil rights case dispositions in federal courts from 1979-2013.64 He found that employment case terminations in federal court declined over time-they peaked with 23,317 cases in 1998 and declined to 16,789 by 2012.65 There were 491,506 employment

62. Id. at 1568. Howard's arbitration numbers are likely inflated by the fact that many of the cases involved individually negotiated arbitration agreements as contrasted with arbitration based on employer-promulgated polices where, as discussed below, the former tend to involve higher-paid employees who may be more sophisticated and betterrepresented than average claimants in employment litigation. See id. at 1569 .

63. $I d$.

64. Theodore Eisenberg, Four Decades of Federal Civil Rights Litigation, $12 \mathrm{~J}$. EMPIRICAL LEGAL STUD. 4, 5 (2015).

65. Id. at 12 . 
discrimination cases terminated between 1979 and 2012.66 Of those cases, 24,009 (4.8\%) reached verdict. ${ }^{67}$ Of those that reached verdict, juries decided 11,994 cases and judges decided 12,015 cases. ${ }^{68}$ Overall, of the cases that went to verdict/judgment, employees won $29.7 \%$ of the time. ${ }^{69}$ In front of juries, they were successful $38.8 \%$ of the time, ${ }^{70}$ but only $20.6 \%$ of the time in bench trials. ${ }^{71}$

The 2014 Colvin-Pike study included a comparison of arbitrations based on unilateral employer policies and arbitrations based on individual contracts. They report a win rate of $24.7 \%$ in the former cases ${ }^{72}$ versus a win rate of $64.6 \%$ in individual contract cases. ${ }^{73}$ In all likelihood, the difference in outcomes reflects the fact that employees with individual contracts are invariably high-wage earners who can hire experienced counsel, do not get a new job right away, have the means to pursue their cases, and have "cause" clauses where the employer has to prove cause-as contrasted with employees working under at-will contracts who have to prove discrimination or another legal violation and generally cannot afford counsel.

Other studies have found somewhat different win rates. For example, Hill found a $34 \%$ employee win rate for arbitrations based on employer-promulgated handbooks, ${ }^{74}$ while Bingham found a $27.6 \%$ win rate for such cases. ${ }^{75}$ Delikat and Kleiner compared 186 arbitrations under security industry rules against employment trials in New York

\footnotetext{
66. Id. at 11 tbl.1.

67. See id.

68. See $i d$.

69. See id.

70. See id.

71. See id. While plaintiffs fare much better with a jury than a judge, the reason is not clear. It could be that (1) juries are more sympathetic to employees; (2) judges know the law better; (3) judges are biased against employees; or (4) judges fear being overturned on appeal. Eisenberg noted that judges dislike being overturned on appeal; pro-plaintiff trial court decisions are overturned $43 \%$ of the time and pro-employer decisions are overturned $10 \%$ of the time. $I d$. at 18 .
}

72. Colvin \& Pike, supra note 58 , at 74 .

73. Alexander J.S. Colvin, Mandatory Arbitration and Inequality of Justice in Employment, 35 BERKELEY J. EMP. \& LAB. L. 71, 75-76 (2014).

74. Elizabeth Hill, AAA Employment Arbitration: A Fair Forum at Low Cost, 58 DISP. RESOL. J. 9, 13 (2003).

75. See Lisa B. Bingham \& Shimon Sarraf, Employment Arbitration Before and After the Due Process Protocol for Mediation and Arbitration of Statutory Disputes Arising out of Employment: Preliminary Evidence That Self-Regulation Makes a Difference, in Alternative Dispute Resolution IN the Employment ARena: Proceedings of the NEW YoRK UNIVERSITY 53RD ANNUAL CONFERENCE ON LABOR, 303, 323 tbl.2 (Samuel Estreicher \& David Sherwyn eds., 2004). 
federal court: claimants won $33.6 \%$ of the time in litigation and $46 \%$ of the time in arbitration. ${ }^{76}$

\section{Repeat Players}

Another focus of empirical work to date involves a comparison of the win rates of employees in arbitrations where the employer is a repeat player as compared to cases where the employer is not a repeat player. ${ }^{77}$ These studies typically define "repeat players" as employers who have had more than one arbitration in the applicable data set. 78 "Repeat employer-arbitrator" combinations are cases where the employers have not only arbitrated before in the data set but have arbitrated before the same arbitrator. ${ }^{79}$ Colvin examined a sample of 836 awards. ${ }^{80} \mathrm{He}$ found that "employees won only 14 out of the 124 cases $(11.3 \%)$ involving a repeat employer-arbitrator pair, compared to 151 out of the 712 cases $(21.2 \%)$ that did not involve a repeat employerarbitrator pair." ${ }^{1}$ The employee win rate against repeat player employers only was higher than that for repeat employer-arbitrator pairs, but the difference was "not statically significant." 82

Do these repeat-player results demonstrate arbitrator bias? Do they suggest that mandatory arbitration presents a forum likely to yield systematically worse results for employees than litigation? Data and research design limitations, in our view, cast doubt over the policy implications that can reasonably be drawn from these studies. First, repeat players are labeled repeat players simply because their second case is in the data set, ${ }^{83}$ but researchers include the first case in

76. Michael Delikat \& Morris M. Kleiner, An Empirical Study of Dispute Resolution Mechanisms: Where Do Plaintiffs Better Vindicate Their Rights?, 58 DISP. RESOL. J. 56, $57-58$ (2003).

77. See Lisa B. Bingham, Employment Arbitration: The Repeat Player Effect, 1 EMP. RTS. \& EMP. POL'Y J. 189, 202 (1997) [hereinafter The Repeat Player Effect]; Lisa B. Bingham, On Repeat Players, Adhesive Contracts, and the Use of Statistics in Judicial Review of Employment Arbitration Awards, 29 MCGEORGE L. REV. 223, 23233 (1998) [hereinafter On Repeat Players].

78. E.g., The Repeat Player Effect, supra note 77, at 207; On Repeat Players, supra note 77 , at 237 .

79. Colvin refers to this "double repeat player" effect as the "repeat employerarbitrator" effect. See Alexander J.S. Colvin, Empirical Research on Employment Arbitration: Clarity Amidst the Sound and Fury?, 11 EMP. RTS. \& EMP. POL'y J. 405, 430 (2007) [hereinafter Colvin, Empirical Research on Employment Arbitration]; Sherwyn, Estreicher \& Heise, supra note 3, at 1571 \& n.6 4 (citing Bingham \& Sarraf, supra note 75, at 323 tbl.2; On Repeat Players, supra note 77, at 323 tbl.2).

80. Colvin, Empirical Research on Employment Arbitration, supra note 79, at 430.

81. Id.

82. Id.

83. Id. 
measuring the repeat players' win/loss record. ${ }^{84}$ This placement begs a critical question: how did the arbitrator in the first case know the employer would be a repeat player and thus arguably have been influenced by the prospect of repeat business with that company.

More importantly, the repeat-player studies make no attempt to control for the size and claims experience of repeat-player employersfactors likely to spell higher win rates for such employers both in litigation as well as arbitration. Our intuition is that repeat players are simply larger, more sophisticated employers with multi-step grievance procedures. Employees are likely to fare worse against these employers as compared to smaller employers with fewer resources and less claims experience irrespective of whether the claim is brought in court or before an arbitrator. The large repeat-player employers are not arbitrating only one-off "for cause" employment contracts with senior executives ${ }^{85}$ Rather, they are arbitrating employment claims for nearly their entire workforce. ${ }^{86}$ Arbitration, moreover, is not the first step in the dispute resolution process promulgated by these employers. Instead, employer-promulgated employment arbitration policies generally contain a multiple-step grievance procedure that includes some form of mediation or peer review before cases can go to arbitration. ${ }^{87}$ Thus, the parties have, in many cases, engaged in a relatively non-adversarial process that allows for settlements or other types of resolutions short of an arbitral award. Strong cases on the merits are likely to be settled; they generally do not result in awards. ${ }^{88}$ Cases that go to hearing are likely to involve relatively weak employee claims pressed by employees who either represent themselves or are represented by inexperienced counsel. Thus, employers that appear in data sets as repeat players or double repeat players should have significantly better win records than non-repeat players. ${ }^{89}$ Similarly, experienced employers should have better win/loss records than inexperienced employers in litigation and before administrative agencies as well. We contend that the proper comparison for repeat-player employers in arbitration should be with repeat-player employers in litigation. We know of no such work.

84. Id. at 431 .

85. See Sherwyn, Estreicher \& Heise, supra note 3 , at 1570.

86. See id.

87. See, e.g., Richard A. Bales \& Jason N.W. Plowman, Compulsory Arbitration as Part of a Broader Employment Dispute Resolution Process: The Anheuser-Busch Example, 26 HofsTRA LAB. \& EMP. L.J. 1, 17-24 (2008); Alexander J.S. Colvin, Employment Arbitration: Empirical Findings and Research Needs, 64 DISP. RESOL. J. 6, 11 (2009) [hereinafter Colvin, Employment Arbitration].

88. See Sherwyn, Estreicher \& Heise, supra note 3, at 1566 n.31.

89. See id. at 1570. 


\section{Damages}

As a general rule, plaintiffs on average receive lower damages in arbitration cases that go to hearing and result in an award than they do in litigation cases that go to trial and result in a verdict/judgment. 90 The median trial verdict/judgment in Eisenberg's 1979-2013 sample was $\$ 153,463 .^{91}$ Delikat and Kleiner compared securities industry arbitrations to employment cases that went to trial in federal court. ${ }^{92}$ The securities industry awards had a mean of $\$ 236,292$ while the mean verdict/judgment in employment litigation cases was $\$ 377,030 .{ }^{93}$ The median award in securities industry arbitrations was $\$ 100,000$ while the median verdict/judgment was $\$ 95,554$ in employment litigation cases. ${ }^{94}$ Eisenberg and Hill found a mean of $\$ 336,291$ and a median of $\$ 150,500$ in 408 federal employment discrimination cases. ${ }^{95}$ Colvin studied 165 AAA employment arbitration cases where the employee was awarded damages and the median award was $\$ 117,715$, and the average award was $\$ 40,624 .{ }^{96}$ Maltby compared arbitration awards to the amounts demanded by the complainants when they filed their claims. ${ }^{97} \mathrm{He}$ found that the mean demand in litigation was $\$ 756,738$ as compared with $\$ 165,128$ in arbitration. ${ }^{98}$ Winning plaintiffs in litigation obtained recoveries that were $70 \%$ of the mean demand at $\$ 530,611$ and successful claimants in arbitration obtained awards that were $25 \%$ of the mean demand at $\$ 49,030 .^{99}$

To understand average awards in arbitration, we need better data on the income levels of successful claimants. Damages in employment cases are based on back pay and less often punitive damages. ${ }^{100}$ It could be the case that arbitration cases resulting in awards feature lowerpaid employees than average claimants in litigations that reach a

90. See Colvin, Employment Arbitration, supra note 87, at 8 (comparing the average expected awards in arbitration cases with those expected in litigation cases).

91. Eisenberg, supra note 64, at 11 tbl.1.

92. Delikat \& Kleiner, supra note 76 , at 57.

93. Id.

94. Id.

95. Theodore Eisenberg \& Elizabeth Hill, Arbitration and Litigation of Employment Claims: An Empirical Comparison, 58 DIsP. RESOL. J. 44, 49 tbl.2 (2004).

96. Colvin, Employment Arbitration, supra note 87, at 8 .

97. . Lewis L. Maltby, Private Justice: Employment Arbitration and Civil Rights, 30 COLUM. HUM. RTS. L. REV. 29, 30 (1998).

98. Id. at 49 tbl.1.

99. Id.

100. Colvin found no punitive damages awards in his arbitration data set, noting that punitive damages are rare in both litigation and arbitration. Colvin \& Pike, supra note 58 , at 77 . 
decision on the merits. ${ }^{101}$ Colvin notes that those pursuing arbitration cases were "lower to middle income" employees making less than $\$ 100,000$ per year. ${ }^{102}$ Thus, the prevalence of lower-paid employees over typically higher-paid plaintiffs in litigation may explain the difference in average awards.

Another factor is time. As a general rule, higher-paid employees take longer to find new employment. If higher-paid employees are better candidates for litigation and are out of work longer than the lower-paid arbitration claimants, then it would stand to reason that their recoveries in litigation would be higher than claimant recoveries in arbitration.

A decisive factor, developed below, is that relatively weaker claims - where claimants are unable to attract competent counsel-are more likely to go to an arbitration hearing on the merits than in litigation to verdict. If so, we should expect average awards in arbitration to be considerably lower than average verdicts/judgments in litigation.

\section{EVALUATION OF EXISTING EMPIRICAL WORK}

\section{A. Using EEOC Filings and Dispositions as a Proxy for the Universe of Employment Law Claims}

To a very considerable extent, the empirical work on employment arbitration consists of a comparison of win rates and size of awards in arbitration with win rates and size of verdicts or judgments in court. ${ }^{103}$ This is an unsatisfying comparison for two reasons. First, litigation and arbitration differ. In litigation, there are substantial hurdles that claims must overcome for a case to result in a verdict or judgment. In arbitration, by contrast, there is reason to believe that employment claims do not face similar hurdles, whether or not claimants are represented by counsel. If this is correct, win rates and size of awards are likely to be lower in arbitration than in court without this difference being very revealing about the comparative merits of arbitration versus litigation.

Second, even if these differences are neither systematic nor significant, what cannot be contested, however, is that the vast majority of employment disputes are not resolved by litigation verdict/judgment

101. See id. at 79 .

102. Id.

103. See supra Part II. 
or arbitration award.104 To put this point more formally, what most scholars study in this setting (cases resulting in verdicts/judgments or arbitration awards) systematically differs from the much broader universe of cases that initiate legal or arbitration processes.

To get a sense of the universe of claims that enter the arbitration process, we need to examine the filing of charges of discrimination with the relevant administrative agencies, notably the federal Equal Employment Opportunity Commission (EEOC) and analogous state and federal agencies. Our assumption is that the overwhelming majority of employment claims, that end up in litigation or arbitration, start out as employment discrimination charges filed with one of the administrative agencies. In the last 20 years, the EEOC received between 75,000 and 100,000 charges each year. ${ }^{105}$ While the exact numbers are difficult to find, we may safely assume that additional filings with state or local agencies are equal to that number. ${ }^{106}$ In the years $2000,2005,2011$, 2012, 2013, 2014, and 2015 the EEOC resolved 671,997 cases with a yearly range from 77,352 (2005) to 112,499 (2011) cases and an average of 96,000 per year. ${ }^{107}$ The EEOC labels its resolutions as either merit or non-merit. ${ }^{108}$ Merit resolutions consist of the following: settlements, successful conciliations, unsuccessful conciliations, and withdrawals with benefits. ${ }^{109}$ Three of these categories result in some

104. Vivian Berger et al., Summary Judgment Benchmarks for Settling Employment Discrimination Lawsuits, 23 HOFSTRA LAB. \& EMP. L.J. 45, 46 (2005).

105. Charge Statistics (Charges Filed with EEOC) FY 1997 Through FY 2017, U.S. EQUAL EMP. OPPORTUNITY COMM'N, https://www.eeoc.gov/eeoc/statistics/enforcement/ charges.cfm (last visited May 3, 2018).

106. See David Sherwyn et al., In Defense of Mandatory Arbitration of Employment Disputes: Saving the Baby, Tossing Out the Bath Water, and Constructing a New Sink in the Process, 2 U. PA. J. LAB. \& EMP. L. 73, 77-78 (1999).

107. All Statutes (Charges filed with EEOC) FY 1997 - FY 2017, U.S. EQUAL EMP. OPPORTUNITY COMM'N, https://www.eeoc.gov/eeoc/statistics/enforcement/all.cfm (last visited May 3 , 2018).

108. See Sherwyn, Estreicher \& Heise, supra note 3, at 1584; Definition of Terms, U.S. EQUAL EMPLOYMENT OPPORTUNITY COMM'N, https:/www.eeoc.gov/eeoc/statistics/ enforcement/definitions.cfm (last visited Jan. 18, 2018).

109. The EEOC defines the terms as follows:

Settlements (Negotiated)[:] Charges settled with benefits to the charging party as warranted by evidence of record. In such cases, EEOC and/or a FEPA is a party to the settlement agreement between the charging party and the respondent (an employer, union, or other entity covered by EEOC-enforced statutes). Successful Conciliation[:] Charge with reasonable cause determination closed after successful conciliation. Successful conciliations result in substantial relief to the charging party and all others adversely affected by the discrimination. Unsuccessful Conciliation [:] Charge with reasonable cause determination closed after efforts to conciliate the charge are unsuccessful. Pursuant to Commission policy, the field office will close the charge and review it for litigation 
sort of "benefit". to the charging party.110 The remaining category, unsuccessful conciliations, is comprised of resolutions where the parties have not resolved the case, there are no benefits obtained, and the employee receives a right-to-sue letter, which is a prerequisite to filing a Title VII lawsuit. ${ }^{111}$

In the years mentioned above, there were 105,181 merit resolutions in which the employee received some (usually monetary) benefit and 20,504 resolutions where the EEOC found cause and the charging party either was given a right-to-sue letter or the EEOC filed a lawsuit on the employee's behalf. ${ }^{112}$ During these years, the EEOC filed 1462 "merit suits" 113 for an average of 209 such actions per year (or $0.2 \%$ of total charges filed). ${ }^{114}$ These 209 court actions represent $7 \%$ of the total number of cases where the agency found cause but could not reach a settlement with the respondent employer. ${ }^{115}$

consideration. NOTE: Because "reasonable cause" has been found, this is considered a merit resolution. Withdrawal with Benefits [:] Charge is withdrawn by charging party upon receipt of desired benefits. The withdrawal may take place after a settlement or after the respondent grants the appropriate benefit to the charging party.

Definition of Terms, supra note 108 (emphasis added).

110. See Sherwyn, Estreicher \& Heise, supra note 3, at 1583-85.

111. Id. at 1584-85.

112. All Statutes (Charges Filed with EEOC) FY 1997 - FY 2017, supra note 107.

113. See EEOC Litigation Statistics, FY 1997 through FY 2017, U.S. EQUAL EMP. OPPORTUNITY COMM'N, https:/www.eeoc.gov/eeoc/statistics/enforcement/litigation.cfm (last visited May 3, 2018). "Merits suits include direct suits and interventions alleging violations of the substantive provisions of the statutes enforced by the Commission and suits to enforce administrative settlements. Intervention is where the EEOC joins a lawsuit that has been filed by a private plaintiff." Id. (emphasis added).

114. Id.; Charge Statistics (Charges Filed with EEOC) FY 1997 Through FY 2017, supra note 105.

115. See supra notes $112-114$ and accompanying text. 
Breakdown of EEOC Cases in 2000, 2005, 2011-2015

\begin{tabular}{|l|c|}
\hline Total Number of Cases Resolved & $\mathbf{6 7 1 , 9 9 7}$ \\
\hline $\begin{array}{l}\text { Total number of merit resolutions in which } \\
\text { employees received some monetary benefit }\end{array}$ & 105,181 \\
$\begin{array}{l}\text { Percent of total cases } \\
\text { Total number of cases in which employees } \\
\text { received a right-to-sue letter or case was filed on } \\
\text { employee's behalf }\end{array}$ & $16 \%$ \\
\hline $\begin{array}{l}\text { Percent of total cases } \\
\text { "metal number of merit resolutions resulting in }\end{array}$ & 20,504 \\
\hline Percent of total cases & $3 \%$ \\
\hline
\end{tabular}

The remaining cases are labeled as non-meritorious. Nonmeritorious cases fall into one of two categories: (1) administrative closures ${ }^{116}$ or (2) no reasonable cause findings. ${ }^{117}$ In these nonmeritorious cases, the employee receives no benefit but is given a rightto-sue letter. ${ }^{118}$ In the years in question, the EEOC labeled 111,971 (16.7\%) resolutions as administrative closings and $434,341(64.6 \%)$ as demonstrating no reasonable cause for a total of 546,312 administrative or no-cause closings or $81.3 \%$ of the cases. ${ }^{119}$ In these cases, the employees, like the 19,042 claimants who received "cause" findings but did not have the EEOC file a lawsuit on their behalf, received right-tosue letters.

\footnotetext{
116. Administrative Closure is a

[C]harge closed for administrative reasons, which include: failure to locate charging party, charging party failed to respond to EEOC communications, charging party refused to accept full relief, closed due to the outcome of related litigation which establishes a precedent that makes further processing of the charge futile, charging party requests withdrawal of a charge without receiving benefits or having resolved the issue, no statutory jurisdiction.
}

Definitions of Terms, supra note 108.

117. "EEOC's determination of no reasonable cause to believe that discrimination occurred based upon evidence obtained in investigation. The charging party may exercise the right to bring private court action." Id. (emphasis added).

118. Equal Employment Opportunity Commission Language Access Plan, U.S. EQUAL EMP. OPPORTUNITY COMM'N, https://www.eeoc.gov/eeoc/plan/lap.cfm (last visited May 3, 2018).

119. All Statutes (Charges Filed with the EEOC) FY 1997 - FY 2017, supra note 107. 
Thus, out of the 671,997 cases resolved by the EEOC in the years studied, $565,354(84.1 \%)$ received right-to-sue letters with no benefits. ${ }^{120}$ While it remains possible that some of these claimants settled the case after receiving their right-to-sue letter, it seems unlikely. To test our intuition, we reached out to 10 prominent management-side employment lawyers and asked if any of them had ever settled a case after the EEOC labeled it as (1) no reasonable cause, (2) administrative closing, or (3) an unsuccessful conciliation. Each lawyer stated that they could not remember ever settling such a case; instead, they waited for the employee to file suit in federal court before they even considered a settlement. This raises the question: how many of the 565,354 administrative or "no-cause" cases end up being filed in federal court? Not very many, we suspect.

In the years we studied, the total number of employment discrimination cases filed in federal court was 105,585 (with a range of 21,032 in 2000 to 11,937 in 2014). ${ }^{121}$ If we assume that claimants receiving an EEOC right-to-sue letter, which is a statutory prerequisite to a Title VII suit, bring an action within the year of receipt, then a lawsuit was filed in $18.7 \%$ of the cases in which the employees such a letter. ${ }^{122}$ We do not know what happened in the $81 \%$ of the cases in which the employee received a right-to-sue letter and no lawsuit eventuated. What were the "benefits" received by the claimants who had their cases fully resolved by the EEOC conciliation? What happened to the cases that were filed in court? We are not aware of any previous work that systematically addresses these questions.

In the 12 months ending in March 2016, the number of employment cases that reached trial (not that were resolved at trial, but just reached that stage of litigation) represented $1.9 \%$ of the Americans with Disabilities Act (ADA) ${ }^{123}$ cases and $2.3 \%$ of the remaining employment discrimination cases. ${ }^{124}$ We cannot be sure if these numbers from 2015-

120. See supra notes 112-119 and accompanying text.

121. U.S. District Courts-Civil Cases Filed, by Nature of Suit, U.S. CouRTS, http:// www.uscourts.gov/sites/default/files/data_tables/Table4.04.pdf (last visited May 3, 2018).

122. We are assuming that the EEOC resolutions in a given year are eligible for a federal court filing in that year $-\mathbf{a}$ reasonable assumption since Title VII requires that suit be brought within 90 days of receipt of the right-to-sue letter. See 42 U.S.C. $\S 2000$ e$5(f)(1)(2012)$.

123. Americans with Disabilities Act of 1990, Pub. L. No. 101-336, 104 Stat. 327 (codified as amended at 42 U.S.C. $\S 12101$ (2012)).

124. See supra note 56 and accompanying text. See Table C-4. U.S. District CourtsCivil Cases Terminated, by Nature of Suit and Action Taken, During the 12-Month Period Ending March 31, 2016, U.S. COURTS, http://www.uscourts.gov/sites/default/files/ data_tables/fjcs_c4_0331.2016.pdf (last visited May 3, 2018), where the federal court 
2016 are representative of each of the years we studied. For purposes of the analysis below, we assume that the 2015-2016 numbers are representative of all the years we studied, use the higher percentage, and, to make the number the most "litigation friendly," assume that all those cases that reached trial actually went to verdict or judgment, as opposed to being settled or otherwise dismissed. Under these assumptions, 2317 cases went to verdict/judgment in the years we studied. If we round up and assume that 2500 cases in the years studied went to verdict/judgment, then $0.37 \%$ of the cases filed with the EEOC in those years went to verdict/judgment. Obviously, inferences based on $0.37 \%$ of the universe of employment discrimination claims are likely fragile, even if these cases are representative of the entire universe of claims, which they are not.

\section{B. Cases Resolved at Trial Are Not Representative of the Universe of Employment Law Claims}

Cases that go to trial are anomalies for a number of reasons. First, plaintiffs' lawyers are rational actors and typically do not take cases unless they see a significant potential return to warrant their time and effort. ${ }^{125}$ They will take cases for settlement purposes that may be relatively weak on the merits but exhibit other characteristics that suggest a prompt resolution. ${ }^{126}$ But unless lawyers are directly compensated by the client or third party for their time, the cases they are willing to expend significant time and effort on are likely to be relatively strong on the merits and suggest recovery of substantial damages. ${ }^{127}$

Since the EEOC finds no merit in at least $80 \%$ of their cases, we can assume that cases with clear liability are rare. ${ }^{128}$ As employers have become more accustomed to employment legislation regulating their

system reported the number of cases that reached trial in a variety of different types of cases. Civil Rights employment was a category as was ADA employment. Id.

125. David Sherwyn \& Michael Sturman, Because It Takes Two: Why Post-Dispute Voluntary Arbitration Programs Will Fail to Fix the Problems Associated with Employment Discrimination Law Adjudication, in 53 ALTERNATIVE DiSPUTE RESOLUTION IN THE EMPLOYMENT ARENA 405, 442 (Samuel Estreicher \& David Sherwyn eds., 2004).

126. Id.

127. Id.

128. See All Statutes (Charges filed with EEOC) FY 1997 - FY 2017, supra note 107. "Charges with outcomes favorable to charging parties and/or charges with meritorious allegations" represented no more than $19.2 \%$ of the "total number of charges filed and resolved under all statutes enforced by EEOC" in any single year between 2010 and 2016 . Id.; Definition of Terms, supra note 108. 
decisions, blatant "smoking guns" will rarely surface. ${ }^{129}$ In addition, employers are generally risk-averse, so if there is clear liability they will likely settle and there will be no trial. ${ }^{130}$ Most of the cases with smoking guns will settle, although a few cases may go to trials because the parties or their counsel disagree on how to value the claims. ${ }^{131}$

The prospect of substantial damages, moreover, will be necessary to attract competent plaintiff counsel to an employment case. ${ }^{132}$ In 1991, Donohue and Siegelman found that absent clear liability, it is economically infeasible for plaintiffs (and by extension their lawyers) to pursue cases where employees earn less than $\$ 450$ per week. ${ }^{133}$ Converting Donohue and Siegelman's finding into 2017 dollars implies that the current threshold is $\$ 787.85$ per week. ${ }^{134}$ According to the Bureau of Labor Statistics, the median wage for all full-time workers in the third quarter of 2017 was $\$ 859 .{ }^{135}$ Breaking it down further, the median weekly income for white men was $\$ 965$, white women $\$ 791$, African American men $\$ 744$, African American women $\$ 658$, Hispanic men $\$ 698$, Hispanic women $\$ 597$, Asian men $\$ 1147$, and Asian women $\$ 902.136$ What this means is that it makes little economic sense for plaintiffs' lawyers, absent relatively clear liability, to take cases for more than half of all part-time employees and more than half of all fulltime African-American and Hispanic employees. ${ }^{137}$ Only slightly more

129. See Eisenberg, supra note 64, at 21,24 ("[T] since 1997 is partly attributable to statutory developments that may have led to temporary case increases while new rights were preliminarily explored.").

130. See Theodore Eisenberg \& Charlotte Lanvers, What Is the Settlement Rate and Why Should We Care?, 6 J. EMPIRICAL LEGAL STUD. 111, 113 (2009) ("Although objective success in litigation can be difficult to define, if a plaintiff is to recover something in a case seeking monetary relief, and therefore to succeed at least in part by an objective measure, recovery is far more likely to be via settlement than via trial.").

131. See generally Eisenberg, supra note 64, at 9 ("The declining number of employment cases over time and an increase in employment case settlement rates over time are evidence that plaintiffs, or their attorneys, are shifting the profile of cases filed.").

132. See Sherwyn, Estreicher \& Heise, supra note 3, at 1574-75.

133. See John J. Donohue III \& Peter Siegelman, The Changing Nature of Employment Discrimination Litigation, 43 STAN. L. REV. 983, 1007-08 (1991).

134. See Elizabeth B. Appelbaum, The Consumer Price Index and Inflation-Calculate and Graph Inflation Rates, MATHEMATICAL ASs'N OF AM., https://www.maa.org/press/ periodicals/loci/joma/the-consumer-price-index-and-inflation-calculate-and-graphinflation-rates (last visited May 3, 2018).

135. Usual Weekly Earnings of Wage and Salary Workers: Third Quarter 2017, U.S. DEP'T OF LABOR (Oct. 18, 2017, 10:00 AM), https:/www.bls.gov/news.release/pdf/ wkyeng.pdf.

136. Id.

137. See id. 
than half of all white women pass the Donohue-Siegelman threshold.138 Thus, if the Donohue-Siegelman estimate is correct, the majority of African-American and Hispanic men and women are excluded from trial data, and only a slight majority of white women are included.

When EEOC charge data are broken down, they reveal that $36 \%$ of all cases are race bias charges and that African-Americans file $82.5 \%$ of these charges while Asian/Pacific Islanders file 3\%. ${ }^{139}$ Claimed national origin discrimination accounts for $11 \%$ of charges and Hispanics filed $50 \%$ of national-origin charges. ${ }^{140}$ Sex discrimination claims make up $30 \%$ of EEOC charges ${ }^{141}$ with a large majority of cases filed by women. ${ }^{142}$ Indeed, only $17 \%$ of all sexual harassment charges are filed by men. ${ }^{143}$ Thus, if we apply the Donohue-Siegelman estimate (as converted into 2017 dollars), one can see that fewer than half of the people in groups that file the majority of claims earn enough money to have a lawyer take their cases to court.

Another factor that influences plaintiff counsels' decision to take on an employment matter is whether the employer will be able to pay the damages. ${ }^{144}$ Unfortunately, we have no data on the size or capitalization of companies that are sued in either federal court or in arbitration.

When plaintiffs' lawyers take on a case, they typically commit substantial resources. ${ }^{145}$ Litigation takes, on average, over two years from filing to resolution. ${ }^{146}$ In addition, since most plaintiffs cannot afford to pay their lawyers' hourly rate, the attorney must take the case on a contingency basis and thus must fund the lawsuit's costs with regard to depositions, experts, etc. ${ }^{147}$ Many plaintiffs' lawyers will not take a case without thousands of dollars in a retainer from the employee. ${ }^{148}$ Thus, often unemployed and modestly paid (when employed) plaintiffs need to not only have a claim exhibiting the prospect of substantial damages from an employer that can afford to pay, they must also be able to afford a side-payment retainer to attract

138. See id.

139. Charge Statistics (Charges filed with EEOC) FY 1997 Through FY 2017, supra note 105.

140. See id.

141. See id.

142. See Charges Alleging Sex-Based Harassment (Charges filed with EEOC) FY 2010 -

FY 2017, U.S. EQUAL EMP. OPPORTUNITY COMM'N, https://www.eeoc.gov/eeoc/statistics/ enforcement/sexual_harassment_new.cfm (last visited May 3, 2018).

143. See id.

144. See Sherwyn, Estreicher \& Heise, supra note 3, at 1574-75.

145. See id. at 1574.

146. See id. at 1572-73.

147. See id. at 1574 n. 88 .

148. See id. at 1574-75. 
the lawyer and have the time to assist the lawyer when needed. The bottom line is that the $0.36 \%$ of the cases that make it to verdict or judgment are not representative of the vast majority of the types of cases filed with the EEOC, state agencies, or in arbitration.

At bottom, selection bias invariably limits comparisons of outcomes in litigation and arbitration. One cannot plausibly infer that the stream of cases that go to arbitration and those that proceed in litigation are comparable in all respects other than what happens to their claims in the two forums. ${ }^{149}$

\section{Possible REsEaRch Designs GoIng Forward}

To better address the critical selection biases that limit comparisons of litigation and arbitration outcomes, we suggest that future studies adopt research designs that incorporate better controls. In this section, we suggest possibly useful approaches for future research in this area.

Studies properly focus in employer-promulgated programs that result in arbitrations. Although critics contend that such programs are unfair because they are designed and implemented by employers

149. We also question the use of limited survey data. It has been argued that employment arbitration presents a "black hole" problem where claims disappear that might otherwise appear on court dockets. See generally Cynthia Estlund, The Black Hole of Mandatory Arbitration, 96 N.C. L. REV. 679 (2018). The argument is based on a comparison of the number of federal employment cases filed in a given year (and an estimate of state court cases) with the number of arbitrations filed in a given year drawn from AAA data compiled in response to California legislation. See supra note 2 and accompanying text. Such comparisons are difficult to make for a variety of reasons. One difficulty is that we do not have reliable information on the number of employers who require mandatory arbitration of employment disputes. Surveys of lawyers who have represented employees in arbitration can at best tell us only what responding lawyers know. See Estlund, supra at 684-85, nn.26-27 (citing ALEXANDER J.S. COLVIN \& MARK D. GOUGH, COMPARING MANDATORY ARBITRATION AND LiTIGATION: ACCESs, ProcESs, AND OUTCOMES 34-35 (2014)). A more recent survey of 527 nonunion employers may add to our body of knowledge, but should not be generalized across all employers. Id. at 689 nn.62-63 (citing ALEXANDER J.S. Colvin, ECON. POLICY INST., ThE Growing UsE OF MANDATORY ARBITRATION (2017), epi.org/135056). We also do not have good information on the number of employment arbitrations. We believe that the Colvin-Gough estimate that $70 \%$ of all arbitrations are conducted under the auspices of two leading arbitration organizations, the AAA and JAMS, see COLVIN \& GOUGH, supra, at 35, vastly overstates their influence in the field. We also note that many employer-promulgated arbitration programs provide for internal steps and mediation before arbitration can occur; these are implemented for the purpose of early dispute resolution and would reduce the incidence of employee claims resulting in arbitration. Professor Estlund's article suggests that in recent years employers have forgone these intermediate steps because their principal interest is in securing class action waivers rather than internal disputes resolution. See Estlund, supra at 698-99. This has not been our experience to date in evaluating company systems, but the existence of any such recent trend warrants further study. 
without employee, union, or government input, ${ }^{150}$ in our experience this has not necessarily been the case. ${ }^{151}$ Rather, we believe most employerpromulgated programs are fairly designed because of the self-interest of employers to have enforceable programs that successfully avoid litigation, ${ }^{152}$ the insistence of leading arbitration organizations on compliance with the requirements of the "due process protocol," 153 and relevant case law on arbitration fees. ${ }^{154}$ Specifically, most employerpromulgated programs (that we are familiar with) provide for several in-house steps, such as internal and/or external mediation, which end in arbitration with a nationally recognized organization (e.g., AAA or JAMS). These organizations maintain rosters of arbitrators experienced in employment law, as well as rules that require disclosure of prior arbitrator involvement with the parties and authorize the award of full statutory remedies if violations are found. ${ }^{155}$

While we are certainly aware of anecdotal accounts of arbitrator policies that feature limited damages, no choice of arbitrator, or other types of unfair procedures, what we do not yet know is whether these "unfair" policies are the small exception or, instead, reflect a real problem in the field.

At the same time, future research will also need to focus on the more than $99 \%$ of the EEOC/litigation cases ${ }^{156}$ and the more than $88 \%$ of the arbitration cases that do not result in a verdict/judgment or award.157 The first question is what is the total number of cases or $n$ ? As stated above, every arbitration policy we have seen contains several steps prior to arbitration. ${ }^{158}$ In a perfect world, we would study all cases where the employment dispute resolution policy was utilized.

Such an approach will be difficult for several reasons. First, existing studies of employer internal dispute systems reveal that almost all cases are resolved in less than one month, and the resolutions often involve disputes that that do not necessarily raise a legally cognizable claim. Second, finding the necessary data would be both difficult and what data can be found may not be representative; in particular, those employers willing to share all of their data are likely to do so because

150. See, e.g., Janna Giesbrecht-McKee, The Fairness Problem: Mandatory Arbitration in Employment Contracts, 50 WILLAMETTE L. REV. 259, 261 (2014).

151. See Sherwyn, Estreicher \& Heise, supra note 3, at 1563-64.

152. See id. at 1560.

153. Id. at 1562 .

154. Id. at 1557-59, 1561-63, 1565, 1582-83.

155. See Sherwyn, Estreicher \& Heise, supra note 3, at 1571.

156. See supra Section IV.A.

157. See supra notes 65-66 and accompanying text.

158. See supra notes 149 and accompanying text. 
they have successful, systems. Employers with poorly designed systems would be correspondingly less willing to share data. Third, the complaints or claims emanating from internal dispute systems are not likely to easily match up with EEOC data. Employers who do not have arbitration policies as such still have harassment and EEO polices, and thus instead of judging arbitration as opposed to EEOC/litigation systems, we would then be looking at different internal dispute resolution programs. For these reasons, we suggest that future researchers focus on cases where an employee goes outside the company's internal processes by filing a charge with the EEOC or filing for arbitration with an external arbitrator.

We are aware of two possible such data sets that hold potential promise. One data set draws from data that AAA makes publicly available: five years of arbitration filings with the Association. ${ }^{159} \mathrm{~A}$ second source of necessary data involves the EEOC's charge data for a similar time period. Specifically, what would be needed is the ability to track down all cases where the EEOC issued a notice of right to sue letter, a prerequisite to a Title VII lawsuit.

Researchers armed with these two sources of data would be comparatively better positioned to study and compare two distinct streams of cases: those investigated and "resolved" by the EEOC, as well as those resolved through arbitration. Of course, there are significantly more cases filed with the EEOC than in arbitration. 160 Specifically, for example, an already-public AAA arbitration data set includes close to 7,500 cases. In contrast, there were approximately 500,000 EEOC cases resolved in the same time period. ${ }^{161}$ Coordinating these two separate data sets to facilitate comparability across them will require attention to an array of practical and logistical factors.

Researchers should endeavor to provide a life history for cases filed in a sample period. It would be important to see whether claimants are represented by counsel and at what stage of the process and whether representation corresponds with systematically different outcomes for claimants. Another critical factor involves settlement activity-when this occurs as well as comparing settled and litigated results for claimants. For those cases that resist settlement, attention should be paid to those cases dismissed by courts prior to trial and by arbitrators prior to hearing, and what the basis for dismissal was (whether the case

159. AAA Consumer Arbitration Statistics, AM. ARB. ASS'N, https://www.adr.org/ Consumer (last visited May 3, 2018).

160. Compare All Statutes (Charges filed with EEOC) FY 1997 - FY 2017, supra note 107, with AAA Consumer Arbitration Statistics, supra note 159.

161. See All Statutes (Charges filed with EEOC) FY 1997 - FY 2017, supra note 107. 
was untimely filed or there was some other jurisdictional failure, or whether there was a summary judgment-type determination on the merits).

It is vitally important that future research undertakes analyses of all initiated disputes rather than on a systematically nonrepresentative fraction of disputes that persist to a verdict/judgment or an arbitrator's award. By so doing, we can begin to address the critical selection-bias problems that severely limit much of the existing literature in this field. Such a research program would be far better positioned to contribute to a scholarly and practical debate that has persisted for nearly three decades: are employees compelled to submit their employment disputes to arbitration worse or better off than employees free to pursue litigation for comparable claims? 